\title{
Ethics of Dietary Guidelines: Nutrients, Processes and Meals
}

\author{
Michiel Korthals ${ }^{1,2}$ (D)
}

Accepted: 10 July 2017/Published online: 21 July 2017

(C) The Author(s) 2017. This article is an open access publication

\begin{abstract}
Dietary guidelines are mostly issued by agrifood departments or agencies of governments, and are the result of power play between interest groups and values. They have considerable influence over food preferences and purchases of consumers. Ethical problems are at stake not only with respect to power strategies and their influence on consumers. In this paper I will consider three different types of guidelines: a nutrient oriented type (like the Dutch or American ones), a process oriented type (Scrinis in Nutritionism: the science and politics of dietary advice, Columbia University Press, New York, 2013) and a meal oriented type (like the Brazilian one). In the nutrient oriented guidelines healthy nutrients and food stuffs are mentioned that excel in containing one or more 'healthy' nutrients. Bio- and nutrition scientists and the producers of nutrients, like the sugar, dairy and animal industry, have a lot of influence in this variant. The nutrient oriented framing of food is focussed on individual health. Individuals are implicitly addressed to take responsibility for their own long term health; they have to acquire surveillance and cognitive skills in interpreting their bio data. They don't need to acquire skills to cook. In the process oriented type, foods and ingredients are categorized according to minimal, refined and reconstituted production processes. Nutrition scientists have the last say here. Consumers do need some food skills to handle fresh products. In the meal oriented guidelines, politicians, social scientists and fresh food producers have prominent responsibilities with respect to the formulation of the guidelines and their application. Buying fresh products, preparing and eating together are the main themes. Food is framed in terms of cooking, and eating and sharing meals. Consumers have to spend time in buying fresh ingredients and cooking; they have to develop food capabilities. The formulation of dietary guidelines is not a neutral
\end{abstract}

Michiel Korthals

michielkorthals@gmail.com

1 Wageningen University, Wageningen, The Netherlands

2 Free University, Amsterdam, The Netherlands 
operation, but determined by controversies about framings of food and health, responsibilities and also by integrity and self-confidence of experts. It is striking that biological and nutrition scientists often proclaim to possess the final truth on the healthiness of nutrients, and heap scorn on diet gurus. They don't care that their often incoherent recommendations cause a lot of confusion with consumers and sometimes even lack of trust. I discuss these themes in the paper and will also give some arguments why in the current situation the meal oriented type is ethically more acceptable.

Keywords Dietary guidelines - Experts - Framing - Power · Nutrients - Meals · Food capabilities

\section{Introduction}

Dietary guidelines are mostly issued by agrifood departments or agencies of governments, and are the result of power play between interest groups and values. They have considerable influence over food preferences and purchases of consumers (Nestle 2007). Not only with respect to this power play and its influence on consumers are ethical problems at stake. As I will show, different types of guidelines attribute different responsibilities to stakeholders and define the role of consumers differently. Some guidelines put full weight on the responsibilities of food processing industries, others on fresh food producers. Not every type of dietary guidelines activates the role of consumers and stimulates consumers' food capabilities in the full sense. I use the concept of capability here, although originally the main protagonists of this concept, like Nussbaum 2006 and Sen 2009, neglect the capabilities to deal with food entirely, i.e. to select ingredients and to use them for a common meal. Both authors analyse mostly health or social capabilities. Some types of dietary guidelines assume minimal food capabilities of consumers and predominately health capabilities or no capabilities at all. All types of dietary guidelines also presuppose that the evidence they are based on is reliable and should be trusted. In this paper I will consider three different types of guidelines: a nutrient oriented one (like the Dutch or American ones), a process oriented one (as far as I know not issued by any governmental agency) and a meal oriented one (like the Brazilian one). The formulation of dietary guidelines is not a neutral operation, but determined by controversies about framings of food and health (what is food?), the role of stakeholders and about integrity (of the agencies that issues them) and selfconfidence (of end-users).

\section{Nutrient Oriented Guidelines}

In nutrient oriented guidelines nutrients or sometimes food stuffs are mentioned that are supposed to be 'healthy', like animal and vegetable proteins, carbohydrates, saturated and unsaturated fats, and vitamins and minerals. Sometimes food products 
are mentioned, like milk, cheese, fruits and meat. These guidelines are mostly formulated by governments or governmental agencies. In this type bio- and nutrition scientists have a lot of influence as well as the producers of nutrients, like the sugar, dairy and animal industry (process industry) (Nestle 2007; Lang et al. 2009). It is striking that the bio- and nutrition scientists mostly proclaim that they have the final truth on the healthiness of nutrients, and they heap scorn on diet 'gurus', mostly dietists that contribute to food hypes like the Paleo diet inventor Loren Cordain or Dr R. Atkins (Fresco 2015; http://www.ad.nl/wetenschap/hoogleraar-natuurlijk-voed sel-is-ongezond afd769c4/; https://www.nrc.nl/nieuws/2017/04/06/e-nummers-zijngeen-vergif-7991921-a1553518). In the Dutch case it is interesting to see that nutrition scientists recommend to eat fish modestly due to the decline of fish species; they cross traditional borders between food and environment. However, other environmental issues are not taken into account, such as the impact of meat production and eating on climate change. The federal agency issuing dietary guidelines of 2015 was ordered by the US government to pay attention to nutrition exclusively and to refrain from environmental considerations, although in the first drafts sustainability arguments were incorporated. Despite huge lobbying of the sugar industry it now recommends to cut back drastically on sugar, and it warns not to eat too much chicken, eggs and meat [Marion Nestle on www.foodpolitics.com; Teicholz 2015)].

The nutrient oriented framing of food is focussed on individual health. Individuals are implicitly addressed to take responsibility for their own long term health, and they have to acquire knowledge skills correspondingly in selecting, buying and consuming food, in interpreting their bodily data (like blood pressure and cholesterol), and to acquire skills of self-surveillance. However, they are not stimulated to acquire food capabilities, i.e. capabilities with respect to preparing meals and connecting them with their life plans and ideals.

\section{Process Oriented Recommendations}

In the second process oriented type, foods and ingredients are differently defined ('framed'). They are categorized in three groups according to minimally, refined and reconstituted production process. Nutrition scientists have the last say here (Scrinis 2013). The first group covers minimally processed whole foods like fruits and vegetables, by for example cutting, cooking or fermenting. The second group is a refined processing of certain ingredients by selecting them, like flour, olive oil and fruit juice. The third group reconstitute a product by adding ingredients and chemical additives; the product is now reshaped (is now 'ultra-processed food'). The guidelines recommend to eat the first unlimited; the second with care and disapprove eating products of the third type.

Food, nutrition and health scientists, technologists and companies have here the most to say because they have to give reliable information on the type of processing of food products. Nevertheless, also common sense of food consumers plays a role here. Consumers have to acquire some food capabilities in being able to distinguish between the different types of processing, to pay attention to and understand labels and other information types to find in what category a food product belongs. They 
also have to exercise and maintain cooking skills. Producers of fresh food are encouraged to produce more; producers of the third type are not stimulated.

\section{Meal Oriented Guidelines}

According to this type food is first and foremost part of a meal. A good example of this orientation is Brazil's new dietary guidelines (Monteiro 2013). The guidelines starts with three "golden rules": Make foods and freshly prepared dishes and meals the basis of your diet; be sure oils, fats, sugar and salt are used in moderation in culinary preparations; limit the intake of ready-to-consume products and avoid those that are ultra-processed.

These rules are specified in ten Brazilian guidelines:

1. Prepare meals from staple and fresh foods.

2. Use oils, fats, sugar and salt in moderation.

3. Limit consumption of ready-to-consume food and drink products.

4. Eat regular meals, paying attention, and in appropriate environments.

5. Eat in company whenever possible.

6. Buy food at places that offer varieties of fresh foods. Avoid those that mainly sell products ready for consumption.

7. Develop, practice, share and enjoy your skills in food preparation and cooking.

8. Plan your time to give meals and eating proper time and space.

9. When you eat out, choose restaurants that serve freshly made dishes and meals. Avoid fast food chains.

10. Be critical of the commercial advertisement of food products.

This type of meal oriented guidelines emerged in Brazil because the country is suffering from the double burden of what is called the nutrition transition (Popkin 1993): which on the one hand produces undernutrition because of lack of micronutrients and on the other hand overweight and obesity due to processed food. The rules presuppose that eating is a social act $(5,6)$ and encourage to develop critical skills of handling food supplies $(7,10)$.

In this type, politicians, social scientists and fresh food producers have the most to say with respect to the formulation of the guidelines. For politicians, their responsibilities are to deliver and maintain social and cultural infrastructures that bring people together for having common meals. Politicians and other stakeholders are encouraged to provide time and occasion for meals. For consumers, buying fresh products, preparing and eating together are the main themes. Food is framed in terms of cooking and eating meals. Consumers have to spend time in searching for and buying fresh ingredients and in preparing and cooking. These food capabilities (Sen 2009) require learning and exercising of 'substantive freedoms' not only with respect to what is healthy, but also to what is tasteful, social acceptable and acceptable according to an individual's life plan and ideals. To have a healthy and tasty meal is the objective of these guidelines, which also means that social processes of choosing, buying, preparing, cooking and eating together are 
emphasized. Consumers have to (learn to) pay attention to what others what to eat, a considerable social capability.

Fresh food producers are encouraged to produce more fresh food and to take care that this food has still sufficient number of vitamins and micronutrients (there is good evidence that the proportion of healthy micronutrients of fresh products such as spinach is declining due to breeding processes).

It is interesting to see that some food writers agree with the third strategy; for example, former food writer with the New York Times, Bittman (2014), formulates only two rules for eating (and living) well:

1. Stop eating junk and hyperprocessed food. This eliminates probably 80 percent of the stuff that is being sold as "food."

2. Eat more plants than you did yesterday, or last year.

If you add "Cook your own food" to this list, it's even more powerful, but these two steps alone allow you to reduce the amount of antibiotics you're consuming; pretty much eliminate GMOs from your diet, lighten your carbon footprint; reduce your chances of becoming ill as a result of your diet; save money; cut way back on sugar, other junk and unnecessary and potentially harmful nonfood additives; and so on.

Even more simple rules are the ones of Michael Pollan (2008): 'Eat food, not too much, mostly plants.'

\section{Guidelines of Type One are not Motivating People to Eat Well}

It is remarkable that although governments and their agencies spend a lot of time in the process of formulating the first type of guidelines, it is quite clear that most consumers do not live up to those guidelines. In the Netherlands, only 5\% (for vegetables and fruit) to $20 \%$ (for fish and salt) of the population orient their food habits on these rules (Nationaal kompas volksgezondheid). In Europe we see a decline in the number of people that follow the rules of their food agencies (all type one; see Figs. 1, 2).

Nevertheless, although these statistics are confronting, the food agencies do not change their approach, and continue by giving recommendations, mostly according to the nutrition type.

(Due to its recent formulation, the third one is not analysed on its impact). Why do people not live up to the guidelines of type one? Although well documented, it is amazing that the explanatory research on this particular topic is scarce. I couldn't find specific literature on this issue. But in general, social scientific research indicates that information campaigns mostly don't reach consumers (Coff et al. 2008) and points to lack of trust in official reports (Gaskell et al. 2011). Stories about the lobbying practices of big food industries also reduce their trustworthiness: when the WHO published its report on the negative consequences of sugar, the sugar industry started an offensive to deny this; when FAO published a report on the detrimental effects of meat, the meat industry denied all the conclusions; when pizza 


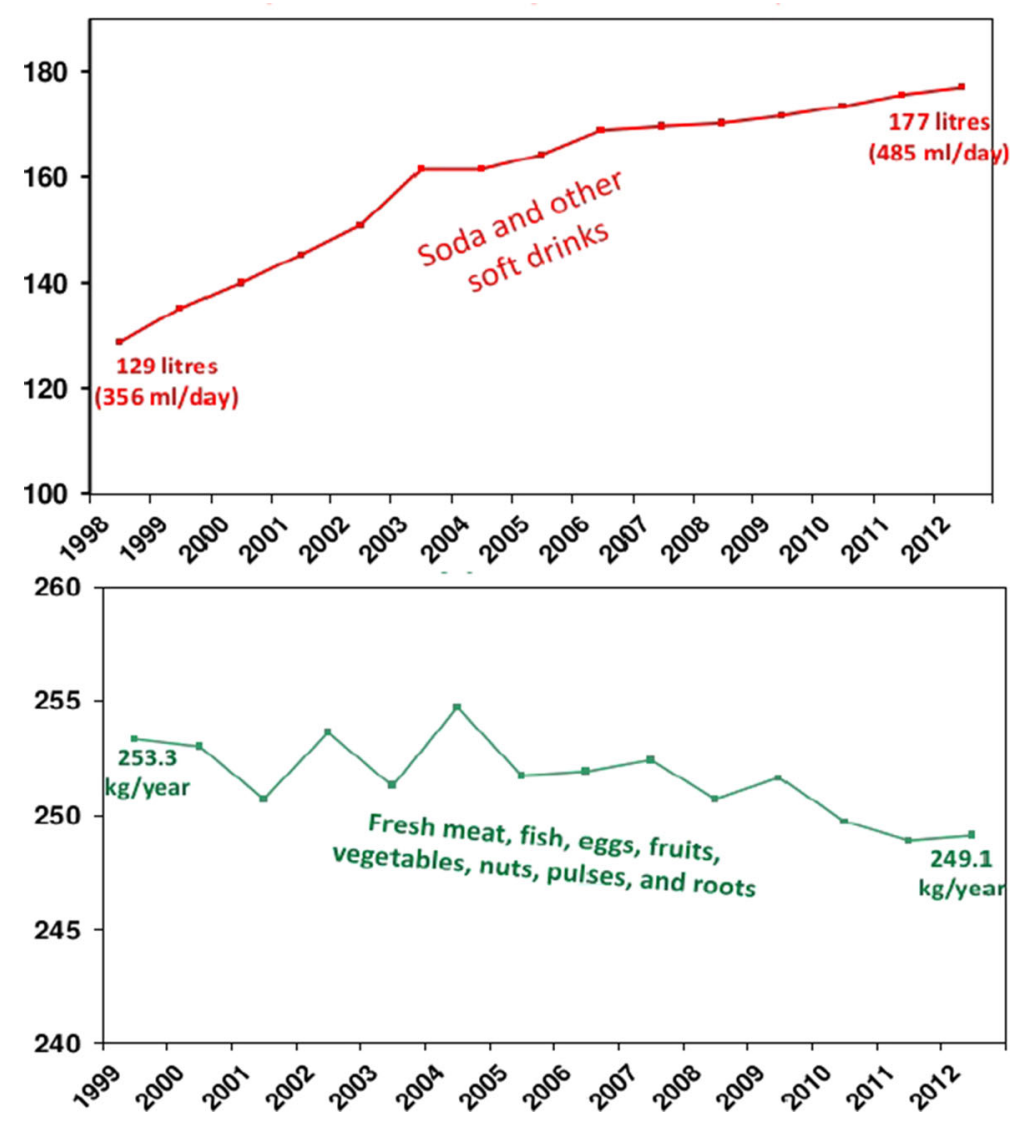

Fig. 1 Per capita supermarket selling of ultra-processed, ready-to-eat food products and minimally processed food products in Europe, 1998-2012. Euromonitor International

was described as a ultra-processed food, industry succeeded in establishing pizza as a vegetable (Moss 2013). Probably this lack of trust is stimulated by the over the years varying guidelines, by these stories of the lobbying practices and also by the incomprehensibility of the official language of the guidelines (proteins, saturated fats etc.). Although in the recent guidelines words like carbohydrates, and proteins are not that often used anymore by the agencies, it is from a common sense point of view clear, that most people don't think in terms of these words; they think in terms of a tasty tomato, tender beef, and fresh cucumber (Heuts and Mol 2013).

So power strategies play probably a negative role with respect to the reliability of the guidelines and the trustworthiness of the institutions. Another aspect that plays a role is the denigrating tone of most food and nutrition scientists towards the public (Coff et al. 2008). Consumers are often treated as (and sometimes even called) ignorant, lazy, hot heads, the weakest link in the food chain and technophobe (Gabriel and Lang 2006; Fresco 2015). Often researchers exaggerate their research on health and nutritional claims in a very ostentative way, as the latest truths (like 


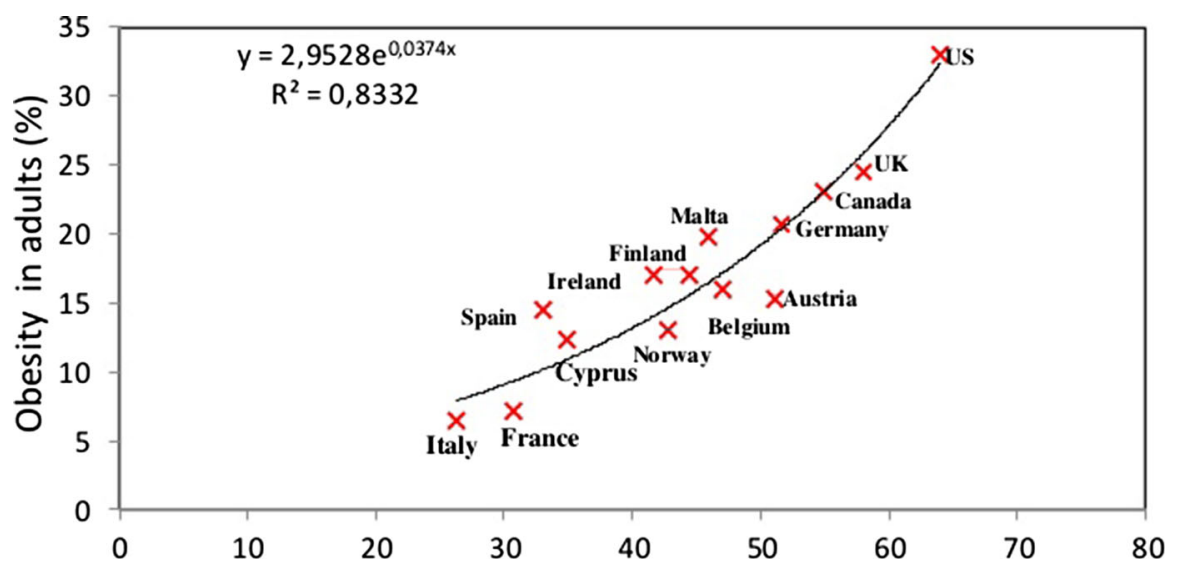

Fig. 2 Association between the selling of processed foods in Europa, US, and obesity, 1991-2010. http:// www.slideshare.net/who_europe/specific-policies-to-tackle-dietrelated-ncd-in-europe

'large portions of meat harm liver', www.eusl.eu), and give so-called food gurus a firm slap in the face. Nevertheless, it happens that later on they take the propositions of gurus seriously, like in the case of carbohydrates, which is now made object of scientific studies.

Moreover, the public is influenced from very different spokespersons by environmental reports by FAO and NGOs about depletion of fish resources and the emptying of the seas and oceans, and on the negative impact of meat production on global warming. That influence also does not motivate to live up to the guidelines, which disregard this information. These guidelines do not say anything about environmental issues, except the Dutch for fish.

It is striking that a major shift in food preferences the last decade, the increasing demand for meat alternatives (be it artificial meat or vegetable alternatives), is not stimulated by these guidelines at all. This shift is stimulated by Ngo's, and their messages. In the end, the guidelines have with respect to consumers only a very limited influence (but probably more on school menus and food services). It becomes urgent that these agencies finally reflect upon what they are doing, what their roles are and how to improve their role.

\section{Political-Philosophical Considerations}

The first type of guidelines considers food as a kind of necessary instrument to stay in life and puts a lot of emphasis to fill the stomach and to monitor this process. Food industry and food scientists play the pivotal role here. Consumers have to follow in the direction these experts think is best: which means taking responsibility for their (narrowly interpreted) health. Nutrients are the main focus. Due to the not often incoherent advices of the scientific experts (normal for science!), the not transparent connections between science and industry, and the often arrogant and exaggerated attacks on so-called food gurus, consumers are often very suspicious 
about the experts' advices, which is mirrored by consumers' non-compliance on a large scale. Only in a very minimal way food capabilities are required.

The second type distinguishes between different types of processing of food, and therefore gives nutritional experts again an important role to play. Consumers are stimulated to pay attention to these different types and they have in that sense to acquire more knowledge about food production than in the first type. However, as in the first type, the social and cultural meanings of food are not recognized.

However, the third type of guidelines starts with a very different framing of food, as a social and cultural device, that has personal and social identity achieving meanings. Cooking, sharing and eating together are the main aims. It takes the body serious, and stimulates people to acquire critical capabilities about processed and novel foods. Indeed, according to many one of the ways to bridge the gap between production and consumption is not by adding more information (as in the first strategy) but by assisting people in getting food capabilities, i.e. skills to learn to selectively deal with new trends in food production and to acquire cooking and sharing skills (capabilities in the sense of Sen 2009). This type doesn't disregard processed foods, but recommends to be careful with their use.

The concept of capability as conceptualised by Sen (2009) develops here its full meaning: freedom doesn't mean access to goods, but to learn and maintain individual capabilities, functionings, with respect to material and non-material goods. Just like all other capabilities, maintaining them is as important as acquiring them, because their non-use or irregular use can diminish their way of working. Sen calls health, safety and cooperation 'primary goods', because all human beings, how different their attitudes and worldviews are, need them. These primary goods correspond with capabilities of individuals: so Sen identifies health and social capabilities. My suggestion is that food has also this universal status, which by the way doesn't mean that everyone wants or has to eat the same food. Food is not only something to fill the stomach and to give energy, but is has also social, psychological and cultural meanings (see the three tomes of Encyclopedia of Food and Agricultural Ethics, 2014). Therefore, food capabilities are as important as health capabilities. Food capabilities consists of critically understanding food information, assessing normatively the way food is produced and exploring taste components of food. Youngsters have to learn them, and later on as adults to maintain them and update them, just like muscles which are always in need of exercise. Governmental food policies should facilitate the training and maintenance of food capabilities.

\section{Conclusion}

The common type of guidelines focusing on nutrients does not stimulate people sufficiently to develop food capabilities. Their expert language and their often incoherent way of formulation increases the distrust that people have regarding them. The third type of guidelines incorporates a philosophy of food that takes seriously both the nutritional and sociocultural meaning of food. These meal oriented guidelines are ethically seen a better instrument to encourage people to 
acquire and maintain good food capabilities. Eating well is a substantial part of living well, and meals are an important factor in the human condition. For to live and eat well are the acquirement and maintenance of food capabilities inevitable. Food policies should facilitate these activities.

Open Access This article is distributed under the terms of the Creative Commons Attribution 4.0 International License (http://creativecommons.org/licenses/by/4.0/), which permits unrestricted use, distribution, and reproduction in any medium, provided you give appropriate credit to the original author(s) and the source, provide a link to the Creative Commons license, and indicate if changes were made.

\section{References}

Bittman, M. (2014). Only two rules for a good diet. The New York Times, October 22.

Coff, Ch., Barling, D., Korthals, M., \& Nielsen, T. (2008). Ethical traceability and communicating food. Dordrecht: Springer.

Fresco, L. (2015). Hamburger in paradise. Princeton: Princeton University Press.

Gabriel, Y., \& Lang, T. (2006). The unmanageable consumer. New York: Sage.

Gaskell, G., Allansdottir, A., Allum, N., Castro, P., Esmer, Y., Fischler, C., et al. (2011). The 2010 Eurobarometer on the life sciences. Nature Biotechnology, 29(2), 113-114.

Heuts, F., \& Mol, A. (2013). What is a good tomato? A Case of Valuing in Practice, Valuation Studies, $1(2), 125-146$.

Kaplan, D., et al. (2014). Encyclopedia of food and agricultural ethics. Dordrecht: Springer.

Lang, T., Barling, D., \& Caraher, M. (2009). Food policy. Oxford: Oxford University Press.

Monteiro, C. A., et al. (2013). Ultra-processed products are becoming dominant in the global food system. Obesity Reviews, 14(Suppl. 2), 21-28.

Moss, M. (2013). Salt, sugar, fat. London: Allen.

Nationaal kompas volksgezondheid, http://www.nationaalkompas.nl/gezondheidsdeterminanten/leefstijl/ voeding/hoeveel-mensen-voldoen-aan-de-richtlijnen-goede-voeding/.

Nestle, M. (2007). Food politics. Cambridge: Harvard University Press.

Nussbaum, M. (2006). Frontiers of justice. Cambridge: Harvard University Press.

Pollan, M. (2008). In defence of food. New York: Colombia University Press.

Popkin, B. M. (1993). Nutritional Patterns and Transitions. Population and Development Review, 19(1), $138-157$.

Scrinis, G. (2013). Nutritionism: The science and politics of dietary advice. New York: Columbia University Press.

Sen, A. (2009). The concept of justice. London: Lane.

Teicholz, N. (2015). The scientific report guiding the US dietary guidelines. BMJ, 321, h4962.

\section{Websites (accessed April 2017)}

http://www.ad.nl/wetenschap/hoogleraar-natuurlijk-voedsel-is-ongezond afd769c4/; https://www.nrc.nl/ nieuws/2017/04/06/e-nummers-zijn-geen-vergif-7991921-a1553518). 